\title{
TOOTH AVULSION MANAGEMENT: STATE OF DENTAL STUDENTS' KNOWLEDGE
}

\author{
Noura A. Al Essa*
}

\begin{abstract}
Aim: This study was conducted to determine the knowledge of undergraduate dental students regarding the management of avulsed teeth at the College of Dentistry, King Saud University, Riyadh, Saudi Arabia.
\end{abstract}

Methods: A self-administered English-language questionnaire contained of 17 close ended questions with two parts: The first part consisted of questions about demographic and professional data. The second part of the questionnaire consisted of questions to evaluate the knowledge and attitude of the students on managing avulsed traumatic injuries. The data were entered and analyzed using SPSS. The level of statistical significance was set at $p<0.05$.

Results: Data were collected from 303 students with response rate of $83.4 \%$. About $80 \%$ of the students had a previous knowledge about dental trauma. Most of the students $92.7 \%$ were able to define avulsion, correct answers were significantly more with advanced academic level $(\mathrm{P}=0.003)$. Majority of the students $(80.5 \%)$ can distinguish between primary and permanent teeth. About half of the study group (46.2\%) correctly answered the ideal time for re-implantation, more female students were responded correctly with $p=0.000$ if compared to male students. Most of the students $(83.8 \%)$ selected milk as a storage medium, almost $15 \%$ selected saliva, $14.5 \%$ selected Hank's balanced salt solution (HBSS) and 8.3\% selected saline. Only 19.8\% answered the flexible splint used for splinting avulsed teeth with significant difference in different academic level and gender $p<0.05$.

Conclusion: The present study reflects insufficient knowledge of dental students in management of avulsed teeth. In some points the students' knowledge needs to be improved through enhancing and providing different kinds of education methods in undergraduate courses.

KEYWORDS: Avulsion; Dental students; Knowledge; Management; Saudi Arabia.

* Division of Pediatric Dentistry, Department of Pediatric Dentistry and Orthodontics, Dental college, King Saud University, Riyadh, Saudi Arabia. 


\section{INTRODUCTION}

Traumatic dental injuries are more common among children and young adults these injuries comprising $5 \%$ of all injuries. About $25 \%$ of school children experience dental trauma and $33 \%$ of adults have experienced trauma to the permanent dentition. ${ }^{1,2}$ Studies showed about $50 \%$ of children have their primary or permanent dentition affected by traumatic injuries during their school days.,

Dental avulsion is the complete displacement of a tooth from its socket in alveolar bone due to trauma. ${ }^{5}$ This type of injury to the permanent teeth is one of the most serious dental injuries, correct emergency management of such injury is very important for better prognosis. ${ }^{1}$ For all dental injuries of permanent teeth, avulsion considered to have $0.5-3 \% .^{6}$ The time interval between the injury and dental treatment, the procedures that are used at the time of injury and the medium in which it was kept until the dentist appointment will determine the prognosis of the avulsed tooth. ${ }^{7,8}$

The management of the avulsion of deciduous and permanent teeth in children is well out-lined in the guidelines of the International Association of Dental Traumatology ${ }^{1}$ and the American Academy of Pediatric Dentistry. ${ }^{9}$

Many avulsed teeth are lost due to lack of knowledge and proper first aid procedures. Dentists' knowledge in the emergency management of avulsed tooth is very important. They are responsible to help these patients to keep their teeth in better health. This study was conducted to evaluate undergraduate dental students at king Saud University, Riyadh, Saudi Arabia regarding clinical examinations, diagnoses, treatments, and prognoses of avulsed teeth in children.

\section{METHODS}

Approval for this study was obtained from the College of Dentistry Research Center at King Saud University. Informed consent was obtained from all participants from the third, fourth and fifth year dental students and only who were willing to participate were included in this survey. Attending clinics and treating patients started from the third year studying at this college, so only third, fourth and fifth year students who were dealing with patients were included. The total number of the students in the college was 363 representing the three levels, 132 students in the third year, 132 students in the fourth year and 99 students in the fifth year.

A self-administered 2-page standardized Englishlanguage questionnaire (Figure: 1) contained 16 close ended questions. The questionnaire consisted of two parts; the questions of the first part were about demographic and professional data which included gender, level of studying, if the student attended any training program of dental trauma, knowledge about tooth avulsion management, and whether they could differentiate between primary and permanent teeth. The second part of the questionnaire consisted of questions to evaluate the knowledge and attitude of the students on managing avulsed traumatic injuries. The questionnaire used was a validated and modified of questionnaires used in previous studies..$^{10,11}$

Before starting distributing the questionnaires for this study, pilot questionnaires were applied for 20 students to evaluate the ease of reading, clarity of the wording and understanding of the questions as it was necessary to check the students' perception and interpretation of the questions, and few modifications were introduced. The students who participated in the pilot study were not included in the final sample.

The dental students were given the questionnaires in the classrooms and asked to fill it out without discussing it with any colleague. Answering the questionnaire took between 5 to 10 minutes. No private informations were requested as the names or contact numbers.

All returned questionnaires were entered and analyzed using SPSS (20.0). Frequencies and percentages were obtained and the Chi-square test was applied to assess the associations between variables. The level of statistical significance was set at $p<0.05$. 


\section{Fig. (1) Questionnaire}

\begin{tabular}{|c|c|c|c|}
\hline 1. & Did you have first-aid training of the dental trauma? & Yes & No \\
\hline 2. & Have you ever experienced an accident of dental trauma? & Yes & No \\
\hline 3. & Do you have previous knowledge about management of avulsed tooth? & Yes & No \\
\hline
\end{tabular}

4. What is tooth avulsion

- Tooth dislodgement of intact tooth out of its socket, due to any trauma*

- Dislodgement of fractured segment of the tooth due to any trauma

- Do not know

5. A 9-year-old girl falls down the stairs and her lips receive a heavy blow. She is bleeding visibly from her mouth, and one upper front tooth is found to be missing. Fortunately, she did not lose consciousness.

-Is the damaged front tooth likely to be a primary or permanent tooth?

$$
\begin{aligned}
& \circ \quad \text { A primary tooth } \\
& \circ \quad \text { A permanent tooth* }
\end{aligned}
$$

-Would you replant (put back) the tooth into the socket from which it avulsed?

$$
\begin{array}{ll}
\circ & \text { Yes* } \\
\circ & \text { No }
\end{array}
$$

6. Can an avulsed permanent tooth be replanted in all cases? Yes No*

7. What is the ideal time for the re-implantation of an avulsed tooth?

$\begin{array}{lll}\circ & 15 \text { mins * } & \circ \\ \circ & 30 \text { mins } & \text { mins } \\ & \circ & 1 \text { hour }\end{array}$

8. You found the knocked out tooth and it is dirty, will you

- Wipe the tooth with tissue paper

- Clean the tooth with a tooth brush

- Rinse the tooth gently under running tap water for a few seconds without scrubbing it*

- No need to clean the tooth because it is useless

- Spray alcohol on the tooth.

- Put the tooth straight back into the socket, with no pretreatment.

9. If liquid is used to transport the tooth, how would you transport it to the dentist?

$\begin{array}{llll}\circ & \text { Milk* } & & \\ \circ & \text { Tap water } & \circ & \text { Alcohol } \\ \circ & \text { Hank's balanced salt solution* } & \circ & \text { Physiological saline* } \\ \circ & \text { Patients saliva* } & \circ & \text { Sports drink. }\end{array}$

10. What is the most critical factor in the outcome of replanted tooth?

$\begin{array}{llll}\circ & \text { Extra alveolar dry time* } & \circ & \text { Storage media } \\ \circ & \text { Splinting period } & \circ & \text { Not sure }\end{array}$

11. Type of splint used is

$\begin{array}{llll}\circ & \text { Rigid } & \circ & \text { Anyone } \\ \circ & \text { Flexible* } & & \text { Not sure }\end{array}$

12. Splinting period is for

$\begin{array}{llll}\circ & 2 \mathrm{wks}^{*} & \circ & 6 \text { wks } \\ \circ & 4 w k s & \circ & \text { Not sure }\end{array}$

13. Which one has better prognosis?

○ Open apex (immature tooth)*

- Closed apex (mature tooth)

14. Should primary tooth be replanted? Yes No*

* Correct answers 


\section{RESULTS}

A total of 303 students from 363 were answered the questionnaires with a response rate of $83.4 \%$. $156(51.5 \%)$ were males and $147(48.5 \%)$ were females, from the third (103), fourth (106) and fifth (94) dental students at King Saud university, (Table 1).

It was found that $74.6 \%$ of the students had the first aid training in dental trauma and approximately $80 \%$ of them had a previous knowledge about dental trauma. Only one-third $33.3 \%$ of participants had exposed to at least one dental trauma cases, (Table 2).

Most of the students $92.7 \%$ were able to define avulsion with significant difference between the students who correctly answered and different academic level $(P=0.003)$. It is obviously that the fifth year students had more knowledge if compared to third year students. Majority of the students $80.5 \%$ knew that the maxillary incisor of 9-year-old girl is permanent tooth with no significant difference
TABLE (1) Distribution of the students based on gender and academic year

\begin{tabular}{|c|c|c|c|}
\hline \multicolumn{2}{|c|}{ Gender } & $\mathbf{N}$ & $\%$ \\
\hline \multicolumn{2}{|c|}{ Males } & 156 & 51.5 \\
\hline \multicolumn{2}{|c|}{ Females } & 147 & 48.5 \\
\hline \multicolumn{2}{|c|}{ Total } & 303 & 100 \\
\hline \multicolumn{2}{|c|}{ Level } & & \\
\hline \multirow{3}{*}{$3^{\text {rd }}$ year } & Males & 54 & 52.4 \\
\hline & Females & 49 & 47.6 \\
\hline & Total & 103 & 100 \\
\hline \multirow{3}{*}{$4^{\text {th }}$ year } & Males & 51 & 48.1 \\
\hline & Females & 55 & 51.9 \\
\hline & Total & 106 & 100 \\
\hline \multirow{3}{*}{$5^{\text {th }}$ year } & Males & 51 & 54.3 \\
\hline & Females & 43 & 45.7 \\
\hline & Total & 94 & 100 \\
\hline
\end{tabular}

TABLE (2) Personal information

\begin{tabular}{|c|c|c|c|c|c|c|c|c|}
\hline \multirow[b]{2}{*}{ Variable } & \multicolumn{3}{|c|}{ Level } & \multirow[b]{2}{*}{ Total } & \multirow[b]{2}{*}{$P$-value } & \multicolumn{2}{|c|}{ Gender } & \multirow[b]{2}{*}{$P$-value } \\
\hline & $3^{\text {rd }}(\%)$ & $4^{\text {th }}(\%)$ & $5^{\text {th }}(\%)$ & & & $\begin{array}{c}\operatorname{Males}(\%) \\
n=156\end{array}$ & $\begin{array}{c}\text { Female }(\%) \\
n=147\end{array}$ & \\
\hline \multicolumn{9}{|c|}{ Have first-aid training of the dental trauma? } \\
\hline Yes & $73(70.9)$ & $81(76.4)$ & $72(76.6)$ & $226(74.6)$ & 0.567 & $128(82.1)$ & $98(66.7)$ & $0.002 *$ \\
\hline NO & $30(29.1)$ & $25(23.6)$ & $22(23.4)$ & $77(25.4)$ & & $28(17.9)$ & $49(33.3)$ & \\
\hline \multicolumn{9}{|c|}{ Have ever experienced an accident of dental trauma? } \\
\hline Yes & $21(20.4)$ & $43(40.6)$ & $37(39.4)$ & 101(33.3) & $0.003^{*}$ & $72(46.2)$ & $29(119.7)$ & $0.000^{*}$ \\
\hline NO & $82(79.6)$ & $63(59.4)$ & $57(60.6)$ & $202(66.7)$ & & $84(53.8)$ & $118(80.3)$ & \\
\hline \multicolumn{9}{|c|}{ Have previous knowledge about management of avulsed tooth? } \\
\hline Yes & $61(59.2)$ & 95 (89.6) & $86(91.5)$ & $242(79.9)$ & $0.000 *$ & $134(85.9)$ & $108(73.5)$ & $0.007 *$ \\
\hline NO & $42(40.8)$ & $11(10.4)$ & $8(8.5)$ & $61(20.1)$ & & $22(14.1)$ & $39(26.5)$ & \\
\hline
\end{tabular}

\section{*Significant}


$p>0.05$ and $84.2 \%$ suggested re-implantation for that lost tooth with significant difference with students' gender, (Table 3).

More than two-thirds $70.3 \%$ knew that the permanent tooth cannot be re-implanted in all cases with significant difference between males and females $p<0.05$. Approximately half of study group $46.2 \%$ correctly answered the ideal time for reimplantation of avulsed tooth which was 15 minutes, female students were more responded correctly with $p=0.000$. About half of the students $54 \%$ would rinse the avulsed dirty tooth gently under running tap water for a few seconds without scrubbing it before re-implantation with a significant difference in different academic level and gender, (Table 4).

Regarding the transport media for avulsed teeth, $83.8 \%$ selected milk as a storage medium, almost $15 \%$ selected saliva, $14.5 \%$ selected Hank's balanced salt solution (HBSS) and 8.3\% selected saline to keep the teeth till seeking professional help. Only $29.4 \%$ correctly answered that the extra alveolar dry time is the most critical factor in the outcome of replanted tooth while 35\% did not know the correct answer, (Table 5).

The splinting type for avulsed teeth, only $19.8 \%$ correctly answered a flexible splint to be used for splinting avulsed teeth with significant difference in different academic level and gender $p<0.05$ females students were more than males who correctly answered this question while $39 \%$ of them believed that the rigid splint should be selected. About onethird $30 \%$ knew the correct splinting period of two weeks while $35.3 \%$ were not sure about the correct answer. Only $36 \%$ responded correctly that avulsed teeth with open apex had better prognosis with significant difference between males and females. From the study sample $77.2 \%$ correctly answered the primary teeth should not be re-implanted, (Table 6).

TABLE (3) Knowledge regarding tooth avulsion according to gender and academic level

\begin{tabular}{|c|c|c|c|c|c|c|c|c|}
\hline \multirow[b]{2}{*}{ Variable } & \multicolumn{3}{|c|}{ level } & \multirow[b]{2}{*}{ Total $(\%)$} & \multirow[b]{2}{*}{ P-value } & \multicolumn{2}{|c|}{ Gender } & \multirow[b]{2}{*}{ P-value } \\
\hline & $3^{\text {rd }}(\%)$ & $4^{\text {th }}(\%)$ & $5^{\text {th }}(\%)$ & & & $\begin{array}{c}\text { Males(\%) } \\
n=156\end{array}$ & $\begin{array}{c}\text { Female }(\%) \\
n=147\end{array}$ & \\
\hline \multicolumn{9}{|l|}{ What is tooth avulsion } \\
\hline \multicolumn{9}{|c|}{ A) Tooth dislodgement of intact tooth out of its socket, due to any trauma $\gamma$} \\
\hline & $89(86.4)$ & $99(93.4)$ & 93(98.9) & 281(92.7) & $0.003 *$ & $143(91.7)$ & $138(93.9)$ & 0.459 \\
\hline \multicolumn{9}{|c|}{ B) Dislodgement of fractured segment of the tooth due to any trauma } \\
\hline & $2(1.9)$ & $6(5.7)$ & $1(1.1)$ & $9(3)$ & 0.121 & $4(2.6)$ & $5(3.4)$ & 0.668 \\
\hline \multicolumn{9}{|l|}{ C) Do not know } \\
\hline & 12(11.7) & $1(0.9)$ & 0 & $13(4.3)$ & $0.000 *$ & $9(5.8)$ & $4(2.7)$ & 0.191 \\
\hline \multicolumn{9}{|c|}{ A 9-year-old girl fall and one upper front tooth is found to be missing. The damaged tooth is: } \\
\hline A) primary tooth & $24(23.3)$ & $24(22.6)$ & 11(11.7) & $59(19.5)$ & & $30(19.2)$ & $29(19.7)$ & 0.913 \\
\hline B) permanent tooth $\gamma$ & $79(76.7)$ & $82(77.4)$ & $83(88.3)$ & $244(80.5)$ & 0.072 & $127(81.4)$ & $117(79.6)$ & 0.690 \\
\hline \multicolumn{9}{|c|}{ Would you replant (put back) the tooth into the socket from which it avulsed? } \\
\hline Yes & $81(78.6)$ & $91(85.8)$ & $83(88.3)$ & $255(84.2)$ & 0.151 & $139(89.1)$ & $116(78.8)$ & $0.015^{*}$ \\
\hline
\end{tabular}


TABLE (4) Questionnaire about re-implantation of avulsed teeth

\begin{tabular}{|c|c|c|c|c|c|c|c|c|}
\hline \multirow[b]{2}{*}{ Variable } & \multicolumn{3}{|c|}{ Level } & \multirow[b]{2}{*}{ Total } & \multirow[b]{2}{*}{$P$-value } & \multicolumn{2}{|c|}{ Gender } & \multirow[b]{2}{*}{$P$-value } \\
\hline & $3^{\text {rd }}(\%)$ & $4^{\text {th }}(\%)$ & $5^{\text {th }}(\%)$ & & & $\begin{array}{c}\operatorname{Males}(\%) \\
n=156\end{array}$ & $\begin{array}{c}\text { Female }(\%) \\
n=147\end{array}$ & \\
\hline \multicolumn{9}{|c|}{ Can an avulsed permanent tooth be replanted in all cases? } \\
\hline Yes & $27(26.2)$ & $37(34.9)$ & $26(27.7)$ & $90(29.7)$ & 0.339 & $61(39.1)$ & $29(19.7)$ & $0.000 *$ \\
\hline No $r$ & $76(73.8)$ & $69(65.1)$ & $68(72.3)$ & $213(70.3)$ & & $95(60.9)$ & $118(80.3)$ & \\
\hline \multicolumn{9}{|c|}{ What is the ideal time for the replantation of an avulsed tooth? } \\
\hline 15 mins $x$ & $46(44.7)$ & $50(47.2$ & $44(46.8)$ & $140(46.2)$ & 0.927 & $49(31.4)$ & $91(61.9)$ & $0.000 *$ \\
\hline 30 mins & $29(28.2)$ & $37(34.9)$ & $28(29.8)$ & $94(31)$ & 0.546 & $64(41)$ & $30(20.4)$ & $0.000 *$ \\
\hline 45 mins & $8(7.8)$ & $3(2.8)$ & $5(5.3)$ & $16(5.3)$ & 0.280 & $14(9)$ & $2(1.4)$ & $0.003^{*}$ \\
\hline 1 hour & $13(12.6)$ & $12(11.3)$ & $16(17)$ & $41(13.5)$ & 0.474 & $19(12.2)$ & $22(15)$ & 0.479 \\
\hline \multicolumn{9}{|c|}{ You found the knocked out tooth and it is dirty, will you } \\
\hline $\begin{array}{l}\text { Wipe the tooth with tissue } \\
\text { paper }\end{array}$ & $12(11.7)$ & 11(10.4) & $3(3.2)$ & $26(86)$ & 0.076 & 18 (11.5) & $8(5.4)$ & 0.058 \\
\hline $\begin{array}{l}\text { Clean the tooth with a tooth } \\
\text { brush }\end{array}$ & $5(4.9)$ & $1(0.9)$ & 0 & $6(2)$ & 0.032 & $5(3.2)$ & $1(0.7)$ & 0.115 \\
\hline $\begin{array}{l}\text { Rinse the tooth gently under } \\
\text { running tap water for a few } \\
\text { seconds without scrubbing } \\
\text { it } \text { \& }\end{array}$ & $45(43.7)$ & $54(50.9)$ & $65(69.1)$ & $146(54.1)$ & $0.001 *$ & $56(35.9)$ & $108(73.5)$ & $0.000 *$ \\
\hline $\begin{array}{l}\text { No need to clean the tooth } \\
\text { because it is useless }\end{array}$ & $8(7.8)$ & $15(14.2)$ & $4(4.3)$ & 27(8.9) & $0.044 *$ & $13(8.3)$ & $14(9.5)$ & 0.716 \\
\hline Spray alcohol on the tooth. & $6(5.8)$ & $11(10.4)$ & $2(2.1)$ & $19(6.3)$ & 0.054 & $6(3.8)$ & $13(8.8)$ & 0.073 \\
\hline $\begin{array}{l}\text { Put the tooth straight back } \\
\text { into the socket, with no } \\
\text { pretreatment. }\end{array}$ & $31(30.1)$ & $25(23.6)$ & $19(20.2)$ & $75(24.8)$ & 0.260 & $66(42.3)$ & $9(6.1)$ & $0.000 *$ \\
\hline
\end{tabular}


TABLE (5) Management of tooth avulsion

\begin{tabular}{|c|c|c|c|c|c|c|c|c|}
\hline \multirow[b]{2}{*}{ Variable } & \multicolumn{3}{|c|}{ Level } & \multirow[b]{2}{*}{ Total } & \multirow[b]{2}{*}{$P$-value } & \multicolumn{2}{|c|}{ Gender } & \multirow[b]{2}{*}{$P$-value } \\
\hline & $3^{\text {rd }}(\%)$ & $4^{\text {th }}(\%)$ & $5^{\text {th }}(\%)$ & & & $\begin{array}{c}\text { Males(\%) } \\
n=156\end{array}$ & $\begin{array}{c}\text { Female(\%) } \\
n=147\end{array}$ & \\
\hline \multicolumn{9}{|c|}{ If liquid is used to transport the tooth, how would you transport it to the dentist? } \\
\hline Milk $\mathrm{y}$ & $86(83.5)$ & 93(87.7) & $75(79.8)$ & $254(83.8)$ & 0.311 & $134(91.7)$ & $111(75.5)$ & $0.000 *$ \\
\hline Tap water & $2(1.9)$ & $13(12.3)$ & $10(10.6)$ & $25(8.3)$ & $0.015^{*}$ & $16(10)$ & $9(6.1)$ & 0.191 \\
\hline Hank's balanced salt solution $r$ & $7(6.8)$ & $20(18.9)$ & $17(18.1)$ & $44(14.5)$ & $0.023 *$ & $23(14.7)$ & $21(14.3)$ & 0.910 \\
\hline Patients saliva ${ }^{r}$ & $6(5.9)$ & $23(21.7)$ & $16(17)$ & $45(14.9)$ & $0.004 *$ & $19(12.2)$ & $26(17.7)$ & 0.178 \\
\hline Alcohol & $5(4.9)$ & $1(0.9)$ & 0 & $6(2)$ & $0.032 *$ & $4(2.6)$ & $2(1.4)$ & 0.452 \\
\hline Physiological saline $\mathrm{r}$ & $6(5.8)$ & $15(14.2)$ & $4(4.3)$ & $25(8.3)$ & $0.022 *$ & $10(6.4)$ & $12(10.2)$ & 0.230 \\
\hline Sports drink & 2(1.9) & 0 & 0 & $2(0.7)$ & 0.142 & $1(0.6)$ & $1(0.7)$ & 0.966 \\
\hline \multicolumn{9}{|c|}{ What is the most critical factor in the outcome of replanted tooth? } \\
\hline Extra alveolar dry time $\mathrm{r}$ & 21(20.4) & $43(40.6)$ & 25(26.6) & $89(29.4)$ & $0.005^{*}$ & $38(24.4)$ & $51(34.7)$ & $0.048^{*}$ \\
\hline Splinting period & $13(12.6)$ & 21(19.8) & $20(21.3)$ & $54(17.8)$ & 0.228 & $37(23.7)$ & 17(11.6) & $0.006^{*}$ \\
\hline Storage media & $20(21.3)$ & $27(25.5)$ & $37(39.4)$ & $71(23.4)$ & $0.000^{*}$ & $27(17.3)$ & $44(29.9)$ & $0.010^{*}$ \\
\hline Not sure & $63(61.2)$ & $23(21.7)$ & $20(21.3)$ & $106(35)$ & $0.000 *$ & $61(39.1)$ & $45(30.6)$ & 0.121 \\
\hline
\end{tabular}

TABLE (6) Management of tooth avulsion

\begin{tabular}{|c|c|c|c|c|c|c|c|c|}
\hline \multirow[b]{2}{*}{ Variable } & \multicolumn{3}{|c|}{ level } & \multirow[b]{2}{*}{ Total } & \multirow[b]{2}{*}{$P$-value } & \multicolumn{2}{|c|}{ Gender } & \multirow[b]{2}{*}{$P$-value } \\
\hline & $3^{\text {rd }}(\%)$ & $4^{\text {th }}(\%)$ & $5^{\text {th }}(\%)$ & & & $\begin{array}{c}\text { Males(\%) } \\
n=156\end{array}$ & $\begin{array}{c}\text { Female(\%) } \\
n=147\end{array}$ & \\
\hline \multicolumn{9}{|c|}{ Type of splint used is } \\
\hline Rigid & $15(14.6)$ & $67(63.2)$ & $37(29.4)$ & 119(39) & $0.000^{*}$ & $74(47.4)$ & $45(30.6)$ & $0.003 *$ \\
\hline Flexible $\mathrm{x}$ & $12(11.7)$ & $13(12.3)$ & $35(37.2)$ & $60(19.8)$ & $0.000^{*}$ & $22(14.1)$ & $38(25.9)$ & $0.020^{*}$ \\
\hline Anyone & $2(1.9)$ & $1(0.9)$ & $3(3.2)$ & $6(2)$ & 0.528 & $3(1.9)$ & $3(2)$ & 0.935 \\
\hline Not sure & $74(71.8)$ & $28(26.4)$ & $19(20.2)$ & $121(39.9)$ & $0.000^{*}$ & $61(39.1)$ & $60(40.8)$ & 0.761 \\
\hline \multicolumn{9}{|c|}{ Splinting period is } \\
\hline 2 wks $r$ & $13(12.6)$ & $45(42.5)$ & $33(35.1)$ & $91(30)$ & $0.000^{*}$ & $34(21.8)$ & $57(38.8)$ & $0.001 *$ \\
\hline 4wks & $14(13.6)$ & $39(36.8)$ & $41(43.6)$ & $94(31)$ & $0.000^{*}$ & $61(39.1)$ & $33(22.4)$ & $0.002 *$ \\
\hline $6 \mathrm{wks}$ & $1(1)$ & $3(2.8)$ & $7(7.4)$ & $11(3.6)$ & 0.045 & $8(5.1)$ & $3(2)$ & 0.151 \\
\hline Not sure & $75(72.8)$ & $19(17.9)$ & $13(13.8)$ & $107(35.3)$ & $0.000 *$ & $53(34)$ & $54(39.7)$ & 0.615 \\
\hline \multicolumn{9}{|c|}{ Which one has better prognosis? } \\
\hline $\begin{array}{l}\text { Open apex } \\
\text { (immature } \\
\text { tooth) }{ }^{\mathrm{r}}\end{array}$ & $34(33)$ & $41(38.7)$ & $34(36.2)$ & $109(36)$ & 0.694 & $45(28.8)$ & $64(43.5)$ & $0.008^{*}$ \\
\hline $\begin{array}{l}\text { Closed apex } \\
\text { (mature tooth) }\end{array}$ & $62(60.2)$ & $65(61.3)$ & $58(61.7)$ & $185(61.1)$ & 0.974 & 103(66) & $82(55)$ & 0.068 \\
\hline \multicolumn{9}{|c|}{ Should primary tooth be replanted? } \\
\hline Yes & $36(35)$ & $25(23.6)$ & $8(8.5)$ & $69(22.8)$ & \multirow{2}{*}{$0.000^{*}$} & $43(27.6)$ & $26(17.7)$ & \multirow{2}{*}{$0.040^{*}$} \\
\hline Nor & $67(65)$ & $81(67.4)$ & $86(91.5)$ & $234(77.2)$ & & $113(72.4)$ & $121(82.3)$ & \\
\hline
\end{tabular}




\section{DISCUSSION}

This study was conducted on university dental students of King Saud University to evaluate the students' knowledge level of dental avulsion. It is very important for this group to understand how to deal and manage such kind of injury as a time is a critical factor in prognosis. These students will be future dentists and can be exposed to any emergency case.

The prognosis for avulsed teeth is varied and depends mainly on the action and the first aid managements will be performed at the site of trauma and the traumatized teeth. There are different treatment choices and mainly depending on the vitality of periodontal ligaments and tooth maturation. ${ }^{1}$

In the present study $74.6 \%$ of the students were had the first aid training in dental trauma, in the other hand only $1.9 \%$ of dental students in Japan were received first aid training in dental trauma. ${ }^{11}$ Approximately $80 \%$ of the sample had a previous knowledge about trauma while about $50 \%$ of Japanese students knew previous knowledge about trauma ${ }^{11}$, it is noticed that third year students had less information compared to fourth or fifth year students $(59.2 \%$ vs. $89,6 \%, 91.5 \%)$, based on the curriculum of this college trauma lectures started in the fourth year and this is an explanation that most of the questions were answered correctly by advanced academic level students .

Most of the students $92.7 \%$ were able to define avulsion which is almost similar to what was found by Limbu et al. (100\%) $)^{12}$ and Abu-Dawoud et al. $(93 \%)^{13}$. Majority of the students $80.5 \%$ can distinguish between primary and permanent teeth this percentage was higher if compared to Japanese students $69.4 \% .{ }^{11}$ From the study group, $84.2 \%$ suggested re-implantation of the lost permanent tooth. The guidelines of International Association for Dental Traumatology (IADT) and American Academy of Pediatric Dentistry (AAPD) emphasized on the immediate re-implantation of an avulsed tooth ${ }^{1,9}$ also it was reported that immediate re-implantation of lost teeth is the treatment of choice for avulsed teeth. ${ }^{14,15}$

International Association for Dental Traumatology (IADT) $)^{1}$ recommended that not all avulsed teeth should be re-implanted as in sever caries or periodontal diseases, un-cooperative children and sever medical conditions (cardiac or immune-compromised patients) in the present study more than two-third of the student agreed not to implant all avulsed teeth. Approximately half of study group knew the ideal time for re-implantation of avulsed tooth which was 15 minutes this finding is in constance with the finding of Limbu et al. study $55 \%{ }^{12}$ that time is also recommended by IADT. ${ }^{1}$ Half of the students (54\%) would rinse the avulsed dirty tooth gently under running tap water for a few seconds without scrubbing it before re-implantation which was suggested by the guidelines of IADT ${ }^{1}$ and AAPD.

If the tooth could not be re-implanted for any reason it should be kept in a medium to prevent the dryness and protect the vitality of periodontal ligaments. ${ }^{16}$ The guidelines of IADT ${ }^{1}$ and AAPD 9 recommended transportation media for avulsed teeth which include Hank's Balanced Salt Solution (HBSS), saline, saliva and milk also these different kinds of media were recommended by previous studies. ${ }^{17,18}$ In the present study $83.8 \%$ of the students selected milk as a storage medium, almost $15 \%$ selected saliva, $14.5 \%$ selected Hank's balanced salt solution (HBSS) and 8.3\% selected saline to keep the teeth till seeking professional help which indicate that the students knew about the storage media that should be used. If comparing between milk and saliva as a storage media Courts et al. ${ }^{19}$ stated that milk has compatible $\mathrm{pH}$ and osmolality to periodontal ligaments cells, so it is better in preserving periodontal ligaments fibroblasts, milk is free of bacteria not as saliva and it is commonly 
available if compared to HBSS in addition it has essential nutrients factors for the cells. It was reported that milk is an excellent storage medium for six hours. ${ }^{20}$ Fortunately in the present study majority of the students selected milk as favorable storage medium for avulsed teeth. Saliva is one choice of a storage medium, but it can damage the periodontal ligaments cells if kept more than one hour. ${ }^{19,21}$ Courts et al. stated that preserving the avulsed teeth in saline for more than two hours it considered as harmful for periodontal ligaments cells. ${ }^{19}$

The chance of damaging periodontal ligaments is increased if extra-oral dry time is increased, it was reported that the most critical factor effecting the prognosis of implanted tooth is extra-oral dry time and there is more chance of having ankylosis within 20 minutes extra-oral time.9, 16, 22 Only $29.4 \%$ correctly answered that the extra-alveolar dry time is the most critical factor in the outcome of replanted tooth while $35 \%$ did not know the correct answer. For any reason if the tooth cannot be implanted within five minutes it should be kept in a medium to preserve the periodontal ligaments. ${ }^{23}$ If the tooth is re-implanted it should be splinted with a flexible type of splint ${ }^{1}$ to allow physiological tooth movement and to prevent anakylosis, only $19.8 \%$ of the present study correctly selected a flexible splint. These results reflect the background knowledge of the student which needs to be improved to enhance the treatment quality for the patients since extra-oral dry time is a critical factor affecting the prognosis. ${ }^{9}$, ${ }^{16,22}$ In addition to the splint type that will affect the outcome of the treatment. ${ }^{1}$

About one-third 30\% knew the correct splinting period of two weeks which is almost similar to a previous study. ${ }^{12}$ IADT and AAPD recommended two weeks splinting will decrease the risk of ankylosis. ${ }^{1,9}$

A chance of having pulp re-vascularization if the avulsed teeth are implanted within 60 minutes is more with immature teeth. ${ }^{24}$ It was reported that immature teeth had better chance of periodontal healing if compared to mature teeth ${ }^{25}$, in the present study $36 \%$ responded correctly that avulsed teeth with open apex had better prognosis and $77.2 \%$ correctly selected that the primary teeth should not be re-implanted. Both IADT and AAPD guidelines recommended that primary teeth should not be re-implanted to reduce the risk of damaging the permanent teeth. ${ }^{1,9}$

One limitation of the study includes: the questionnaires were distributed to the students and filled by themselves, if there were interviews with the students this will help to explain any unclear items to get better results.

\section{CONCLUSION}

Dental students' knowledge for management of avulsed teeth considered to be insufficient. In some points the students' knowledge needs to be improved through emphasizing more on continuous education and applying different kinds of education methods about management of such trauma to improve their knowledge so they can manage such a case independently as the time is an important factor of having good prognosis.

\section{REFERENCES}

1. International Association of Dental Traumatology guidelines for the management of traumatic dental injuries: 2. Avulsion of permanent teeth. Dent Traumatol. 2012; 28:88-96.

2. Glendor U, Halling A, Andersson L, Eilert-Peterson E. Incidence of traumatic tooth injuries in children and adolescents in the county of Västmanland, Sweden. Swed Dent J. 1996; 20:15-28.

3. Young C, Wong KY, Cheung LK. Emergency management of dental trauma: Knowledge of Hong Kong primary and secondary school teachers. Hong Kong Med J. 2012;18(5):362-70.

4. Andreasen JO, Ravn JJ. Epidemiology of traumatic dental injuries to primary and permanent teeth in a Danish population sample. Int J Oral Surg. 1972;1:235-9. 
5. Chappuis V, Von Arx T. Replantation of 45 avulsed permanent teeth: A 1 year follow up study. Dent Traumatol. 2005;21(5):289- 96

6. Andreasen JO, Andreasen FM. Avulsions. In: Andreasen JO, Andreasen FM, Andersson L, editors. Textbook and color atlas of traumatic injuries to the teeth, 4th ed. Oxford, UK: Wiley-Blackwell; 2007. 444-88.

7. Flores MT, Andersson L, Andreasen JO, Bakland LK, Malmgren B, Barne F et al. Guidelines for the management of traumatic dental injuries II. Avulsion of permanent teeth. Dent Traumatol. 2007;23:130-6.

8. Andersson L, Andreasen JO, Day P, Heithersay G, Trope $\mathrm{M}$, DiAngelis AJ et al. Interna onal Associa on of Dental Traumatology guidelines for the management of traumatic dental injuries: 2. Avulsion of permanent teeth. Dental Traumatol. 2012;28:88-96.

9. American Academy of Pediatric Dentistry. Guideline on management of Acute Dental trauma. Pediatr Dent. 2011;33(2):222-8.

10. Subhashraj K. Awareness of management of dental trauma among medical professionals in Pondicherry, India. Dent Traumatol. 2009;25(1):92-4

11. Fujita Y, Shiono Y, Maki K.. Knowledge of emergency management of avulsed tooth among Japanese dental students. BMC Oral Health. 2014;14:34

12. Limbu S, Dikshit P, Bhagat T, Mehata S. Knowledge of Dental Interns towards Emergency Management of Avulsed Tooth in Dental Colleges in Nepal. J Nepal Health Res Counc. 2014;12(26):1-7.

13. Abu-Dawoud M, Al-Enezi B, Andersson L. Knowledge of emergency management of avulsed teeth among young physicians and dentists. Dent Traumatol. 2007;23:248-55.

14. Upadhyay S, Rokaya D, Upadhyaya C. Knowledge of emergency management of avulsed teeth among general dentists in Kathmandu. Kathmandu Univ Med J. 2012;38(2):37-40.
15. Andreasen, J.O. and Andreasen, F.M. Text book and color atlas of traumatic injuries to the teeth. $3^{\text {rd }}$ ed. Copenhagen, Denmark: Munksgaard; 1994.

16. Sigalas E, Regan JD, Kramer PR, Witherspoon DE, Opperman LA: Survival of human periodontal ligament cells in media proposed for transport of avulsed teeth. Dent Traumatol. 2004;20:21-8.

17. Barrett EJ, Kenny DJ: Survival of avulsed permanent maxillary incisors in children following delayed replantation. Endod Dent Traumatol. 1997;13:269-75.

18. Yanxiang Zhao, Yi Gong. Knowledge of emergency management of avulsed teeth: A survey of dentists in Beijing, China. Dent Traumatol. 2010;26:281-4.

19. Courts FJ, Mueller WA, Tabeling HJ. milk as an interim storage medium for avulsed teeth. Pediatr Dent. 1983;5(3):183-6.

20. Blomlöf L, Lindskog S, Andersson L, Hedström KG, Hammarström L. Storage of experimentally avulsed teeth in milk prior to replantation. J Dent Res. 1983;62(8):912-6.

21. Layug ML, Barrett EJ, Kenny DJ. interim storage of avulsed permanent teeth. J Can Dent Assoc. 1998;64(5):357-63, 365-9.

22. Andreasen JO, Borum MK, Jacobsen HL, Andreasen FM. Replantation of 400 avulsed permanent incisors. Factors related to periodontal ligament healing. Endod Dent Traumatol. 1995;11:76- 89.

23. GoswamiM, ChaitraT, ChaudharyS, ManujaN, SinhaA. Strategies for periodontal ligament cell viability: An overview. J Conserv Dent. 2011;14:215-20.

24. Cvek M, Cleaton-Jones P, Austin J, Lownie J, Kling M, Fatti P. Pulp revascularization in reimplanted immature monkey incisors - Predictability and the effect of antibiotic systemic prophylaxis. Endod Dent Traumatol. 1990;6(4):157-69.

25. Trope M, Chivian N, Sigurdsson A, Vann WF Jr. Traumatic injuries. In Cohen S, Burns RC, editors. Pathways of the

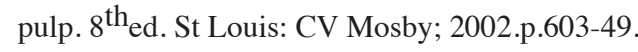

